$\begin{array}{cc}\text { ACADEMIA ROMÂNĂ } & \text { Rev. Roum. Chim., } \\ \text { Revue Roumaine de Chimie } & \text { 201(10), 909-913 } \\ \text { http://web.icf.ro/rrch/ } & \text { DOI: 10.33224/rrch.2019.64.10.10 }\end{array}$

\title{
ANTIOXIDANT AND ANTIDIABETIC PROPERTIES OF POLYPHENOLIC-RICH EXTRACTS OF APIUM GRAVEOLENS AND AGROPYRUM REPENS
}

\author{
Elena NEAGU, ${ }^{\text {a }}$ Gabriela PĂUN, ${ }^{\text {a }}$ Veronica MOROEANU, ${ }^{\mathrm{a}}$ \\ Oana UNGUREANU ${ }^{\mathrm{a}}$ and Gabriel Lucian RADU ${ }^{\mathrm{b}, *}$ \\ ${ }^{a}$ Centre of Bioanalysis, National Institute of Research and Development for Biological Sciences, \\ 296 Splaiul Independentei, 060031, Bucharest 6, Roumania \\ ${ }^{\mathrm{b}}$ Faculty of Applied Chemistry and Materials Science, University Politehnica of Bucharest, \\ Str. Gh. Polizu, Nr. 1-7, 011061 Bucharest 1, Roumania
}

Received January 30, 2019

Due to the increase of the incidence of type II diabetes nowadays there are attempts to find phytotherapeutic alternatives for the prophylaxis of this disease by inhibiting the enzymes involved in glucose uptake. Thus, in this study the $\alpha$-amylase and $\alpha$-glucosidase inhibitory activities of some hydroalcoholic Apium graveolens and Agropyrum repens extracts (50\% EtOH, v/v, 10\% weight) were analysed. Extracts were processed by membranare processes, microand ultrafiltration for obtaining rich-polyphenolic extracts. The polyphenols and flavones content and antioxidant activity of them were analysed. The extracts of both plants have shown inhibitory activities on the two digestive enzymes.

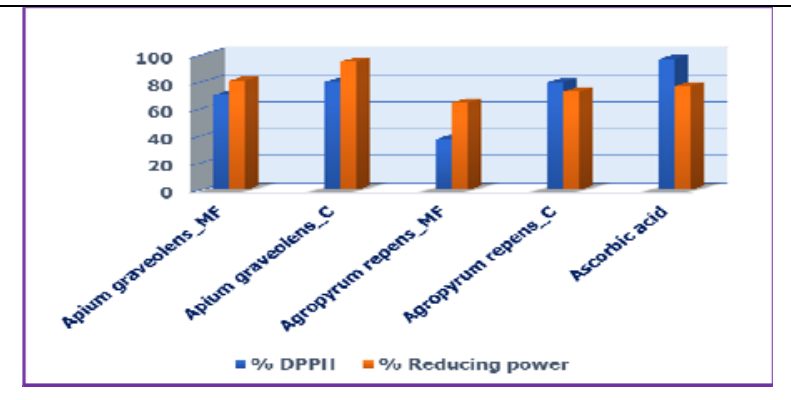

\section{INTRODUCTION}

Diabetes mellitus is a metabolic disorder with multiple etiology and long-term effects on several organs. ${ }^{1}$ The incidence of this disease is steadily rising and expects an increase in over 300 million cases in $2025 .^{2}$ In the management of type II diabetes, one approach is to reduce postprandial hyperglycaemia by administering drugs that inhibit digestive enzymes - such as $\alpha$-amylase and $\alpha$ glucosidase - thus reducing the intestinal absorption rate of glucose.

$\alpha$-amylase is secreted by the pancreas and hydrolyses the starch in maltose, isomaltose and oligomaltose which can not be absorbed by the intestine. ${ }^{3}$ The intestinal $\alpha$-glucosidases (maltose, isomaltose and saccharose) are involved in the final stage of hydrolysis of carbohydrates in order to obtain the absorption of monosaccharides. ${ }^{3,4}$

Enzymatic inhibitors attenuate postprandial hyperglycaemia and also provide secondary health benefits such as: moderation in plasma triglycerides, moderation of arterial hypertension due to reduced glucose toxicity and improved insulin response. ${ }^{5}$

Plants and herbal preparations have been used from ancient times for the treatment of diabetes mellitus and are still used in traditional medicine. ${ }^{6}$ Lately, researches have sought to find natural enzyme inhibitors of various herbs and medicinal herbs with little side effects compared to chemical inhibitors and low costs. ${ }^{7}$

\footnotetext{
*Corresponding author. email:gl_radu@chim.upb.ro
} 
Apium graveolens Linn. (Celery), an annual herb belonging to family Apiaceae, is found in North and South Americas, Southern Europe, Africa and Asia. Celery is used in various forms such as fresh herb, stalk, seeds, oil for flavouring of foods and for medicinal purposes. The roots, leaves and seeds of Apium contain sedanolide, linoleic acid, flavonoids, phenolic compounds, volatile oil and L-3-n-butylphthalide. ${ }^{8-10}$ That pure compound extracted from A. graveolens (L-3-nbutylphthalide) was demonstrated to improve cognitive impairment in the Alzheimer's mouse model. $^{8}$ Its synthesized compound, DL-3-nbutylphthalide, has shown neuroprotective effects on cerebral ischemia induced Parkinson's disease. ${ }^{11}$ More studies have reported the pharmacological effect of this herb on antimicrobial, antiinflammatory, hypotension, hypolipidemic, antiarthritis, antiulcerogenic activity. ${ }^{9}$

Agropyrum repens (L.) P. Beauv. (sin. Triticum repens L., sin. Elymus repens L.) (couch grass, quack grass, graminis rhizoma) (Synonym of Elymus repens (L.) Gould) (Poaceae), is a grass species native to Europe and Asia. In folk medicine, its rhizome has been used to treat nephritis, urethritis and urinary calculi. ${ }^{12}$ Rhizomes contain polysaccharides, quercetin and luteolin glycosides, ${ }^{13}$ phenolic glucosides, mainly the 5glucosides of 5-hydroxyindole-3-acetic acid and 5 hydroxytryptophan, ${ }^{14,15}$ phenolic acids, ${ }^{16}$ about $0.02 \%$ of volatile oil ${ }^{17}$ sugar alcohols, ${ }^{18}$ phydroxycinnamic esters, ${ }^{19}$ and fatty acids.

In this study the antidiabetic potential of Apium graveolens and Agropyrum repens extracts was analysed by testing the activity of inhibiting $\alpha$ amylase and $\alpha$-glucosidase activity.

\section{EXPERIMENTAL}

\section{Chemicals}

All chemicals and solvents were purchased from Sigma Chemical Company (Sigma Aldrich, Germany), Fluka (Switzerland), Roth (Carl Roth GmbH, Germany) and deionized water was used for all the performed analysis (Millipore, Bedford, MA).

\section{The obtaining and concentration of extracts}

The $50 \%$ ethanolic extracts ( $10 \%$ mass) were obtained and the mixtures were sonicated for $1 \mathrm{~h}$ at room temperature, then filtered, through a Whatman filter. The extract concentration was realized by ultrafiltration using Millipore membranes with
3.000 Da cut-off. The concentration ratio (expressed as volumes' ratio between permeate and concentrate) was of 3:1. A KMS Laboratory Cell CF-1 installation, purchased from Koch Membrane firm - Germany, was used for both microfiltration and ultrafiltration.

\section{Determination of total bioactive compounds}

Total polyphenols contents determination was done by the Folin-Ciocalteu method. ${ }^{20}$ The polyphenols' concentration in sample was calculated based on an etalon curve of 10$100 \mu \mathrm{g} / \mathrm{mL}$ gallic acid (GAE).

Total flavonoid contents determination was done using the spectrophotometric method described in "Farmacopeea Romana" $X^{\text {th }}{ }^{21}$ The flavones content express in $\mu \mathrm{g}$ rutin equivalent $(\mathrm{RE}) / \mathrm{mL}$ of extract, was calculated using the calibration curve obtained in the $0-120 \mu \mathrm{g} / \mathrm{mL}$ concentration range.

\section{Antioxidant assays}

The antioxidant activity was measured using 2 methods:

\section{DPPH radical scavenging activity ${ }^{22}$}

The scavenging activity on the DPPH radical of samples was determined by measuring the decrease in the DPPH maximum absorbency at $517 \mathrm{~nm}$ after $3 \mathrm{~min}$ and was calculated:

radical scavenging activity $(\%)=\left[\left(\mathrm{A}_{\mathrm{B}}-\mathrm{A}_{\mathrm{A}}\right) / \mathrm{A}_{\mathrm{B}}\right] \times 100$ where: $\mathrm{A}_{\mathrm{B}}=$ control absorbance and $\mathrm{A}_{\mathrm{A}}=$ sample absorbance.

Reducing Power Activity (Iron (III) to iron (II) reduction)

Reducing power was determined according to a previously described procedure ${ }^{23}$. The absorbance was measured spectrophotometrically at $700 \mathrm{~nm}$ and calculation was done using the formula:

$$
\text { Reducing power }(\%)=\left[\left(\mathrm{A}_{\mathrm{A}}-\mathrm{A}_{\mathrm{B}}\right) / \mathrm{A}_{\mathrm{A}}\right] \times 100
$$

where: $A_{A}=$ sample absorbance, $A_{B}=$ control absorbance

\section{Enzyme inhibitory activity assay}

\section{$\alpha$-Amylase inhibition assay}

The $\alpha$-amylase inhibition assay was performing using the Ranilla method with slight modification (2010). ${ }^{24}$ The absorbance was measured at $540 \mathrm{~mm}$ using a UV-visible spectrophotometer (Jasco- V630). Acarbose was used as positive control. The inhibition of enzyme activity was calculated as follows:

$$
\% \text { amylase inhibition }=\frac{\Delta A_{\text {control }}-\Delta A_{\text {sample }}}{\Delta A_{\text {control }}} \times 100
$$

\section{$\alpha$-Glucosidase inhibition assay}

The $\alpha$-glucosidase inhibition assay was performing using the P. Mccue et al. method with slight modification $(2005){ }^{25}$ The absorbance was recorded at $405 \mathrm{~nm}$ using a UV-visible spectrophotometer. Acarbose was used as positive control. The inhibition of enzyme activity was calculated as follows:

$$
\% \text { glucosidase inhibition }=\frac{\Delta A_{\text {control }}-\Delta A_{\text {sample }}}{\Delta A_{\text {control }}} \times 100
$$




\section{RESULTS AND DISCUSSION}

\section{The determination of total polyphenolic and flavones content}

Phenolic acids and flavones are the two main groups of phenolic compounds in herbs. Phenolic acids have a wide range of biological activities such as antioxidant activity, protection against coronary heart diseases, anti-inflammatory, anticancer and antimicrobial activities. ${ }^{26}$

The flavonoids are a prominent group of secondary metabolites in plant that may possess biological activity and have beneficial effects on human health as antimicrobial, anti-inflammatory, anti-diabetic, anti-cholesterolemic, antioxidant and anti-cancer agents. ${ }^{27,28}$

The results regarding the content in polyphenols and flavones of Apium graveolens and Agropyrum repens extracts were showed in Table 1 . The content in bioactive compounds was higher in the concentrate extracts than in the initial microfiltrates. The highest content of polyphenols - $764.54 \mu \mathrm{g} \mathrm{GAE} / \mathrm{mL}$ was recorded in the concentrated extract of Apium graveolens, while the flavone content was similar for the concentrated extracts of both plants.

\section{Antioxidant activity determination}

The antioxidant capacity of plant extracts is largely due to the presence of different types of phenolic compounds in plants. Phenols possess the free radical scavenging activity by the presence of high reactivity as hydrogen or electron donors. ${ }^{29}$ They are strong antioxidants due capable of removing free radicals, chelate metal catalysts, activate antioxidant enzymes, reduce $\alpha$-tocopherols radicals and inhibit oxidases. ${ }^{30}$

Numerous studies have shown that other compounds such as flavonoids and flavonoid derivatives - isoflavones, flavones, anthocyanins, catechin and isocatechin, have antioxidant activity and could therefore reduce cellular oxidative stress. ${ }^{30,31}$

The experiments performed identified a direct correlation between the polyphenols content and the antioxidant capacity of the extracts $(\mathrm{p}<0.05 \%)$. Thus, extracts that had the highest polyphenol content showed the highest antioxidant activity.

It was found a high antioxidant activity for both extracts (by both methods) higher for concentrated extracts than microfiltrate and for concentrated Apium graveolens extracts $>90 \%$, even higher than the standard used, ascorbic acid $(76.81 \%$ by reducing power), extracts witch has had the largest amount of polyphenols (Fig. 1).

\section{$\alpha$-amylase and $\alpha$ glucosidase inhibition assay}

$\alpha$ amylase and $\alpha$ glucosidase are important enzymes in carbohydrate metabolism. Inhibition of these enzymes slows down carbohydrate digestion by decreasing the glucose uptake rate, which may be a possible approach to type II diabetes. ${ }^{32,33}$

This is the first report regarding the inhibitory effect of these plants on $\alpha$-amylase and $\alpha$ glucosidase.

Apium extracts exhibit an inhibitory activity on $\alpha$-amylase greater than that of Agropyrum extracts and even higher than the reference standard (Acarbose: $I_{\alpha \text {-amylase }}=73 \%$ ). The concentrated extract of Apium also recorded the highest inhibitory activity on $\alpha$-amylase, over $90 \%$, which correlates with polyphenol content and antioxidant activity. This is consistent with literature data that attributes antioxidant character and inhibitory capacity to enzymes of polyphenolic compounds, ${ }^{34}$ although other authors attribute these properties to the interaction of phenolic and non-phenolic compounds. $^{24}$

Anti-glucosidase activity was similar for both plants, respectively $34.75 \%$ - Apium si $34.58 \%$ Agropyrum, and lower than the standard used Acarbose: $\mathrm{I}_{\alpha \text {-glucosidase }}=47.9 \%$ (Fig. 2).

Table 1

The bioactive compounds content of extracts

\begin{tabular}{clcc}
\hline Samples & & $\begin{array}{c}\text { Polyphenols } \\
\boldsymbol{\mu g G A E} / \mathbf{m L}\end{array}$ & $\begin{array}{c}\text { Flavones } \\
\boldsymbol{\mu g R U} / \mathbf{m L}\end{array}$ \\
\hline Apium graveolens & MF & 590 & 49.83 \\
Agropyrum repens & $\mathrm{C}$ & $\mathbf{7 6 4 . 5 4}$ & 86.52 \\
& $\mathrm{MF}$ & 257.95 & 70.89 \\
& $\mathrm{C}$ & 412.62 & 85.05 \\
\hline
\end{tabular}

MF - microfiltrate; $\mathrm{C}$ - concentrate;

Values represent mean standard deviation of triplicate experiment. 


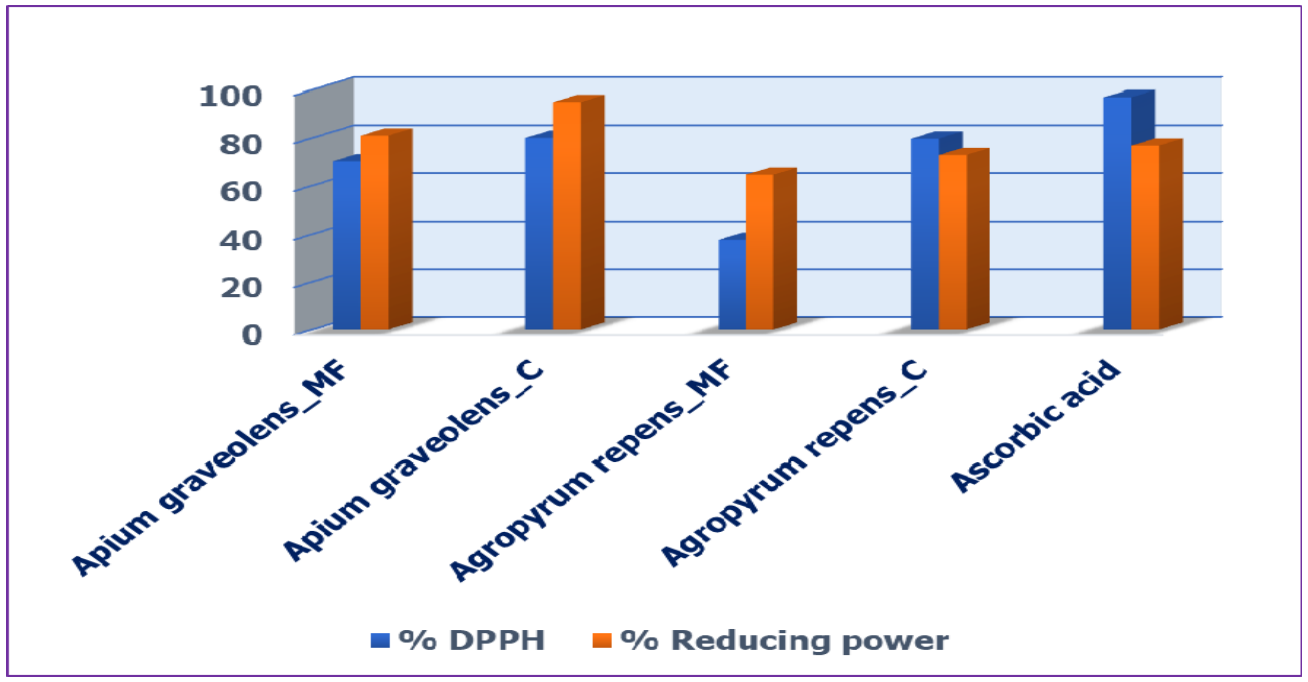

Fig. 1 - Antioxidant activity of extracts.

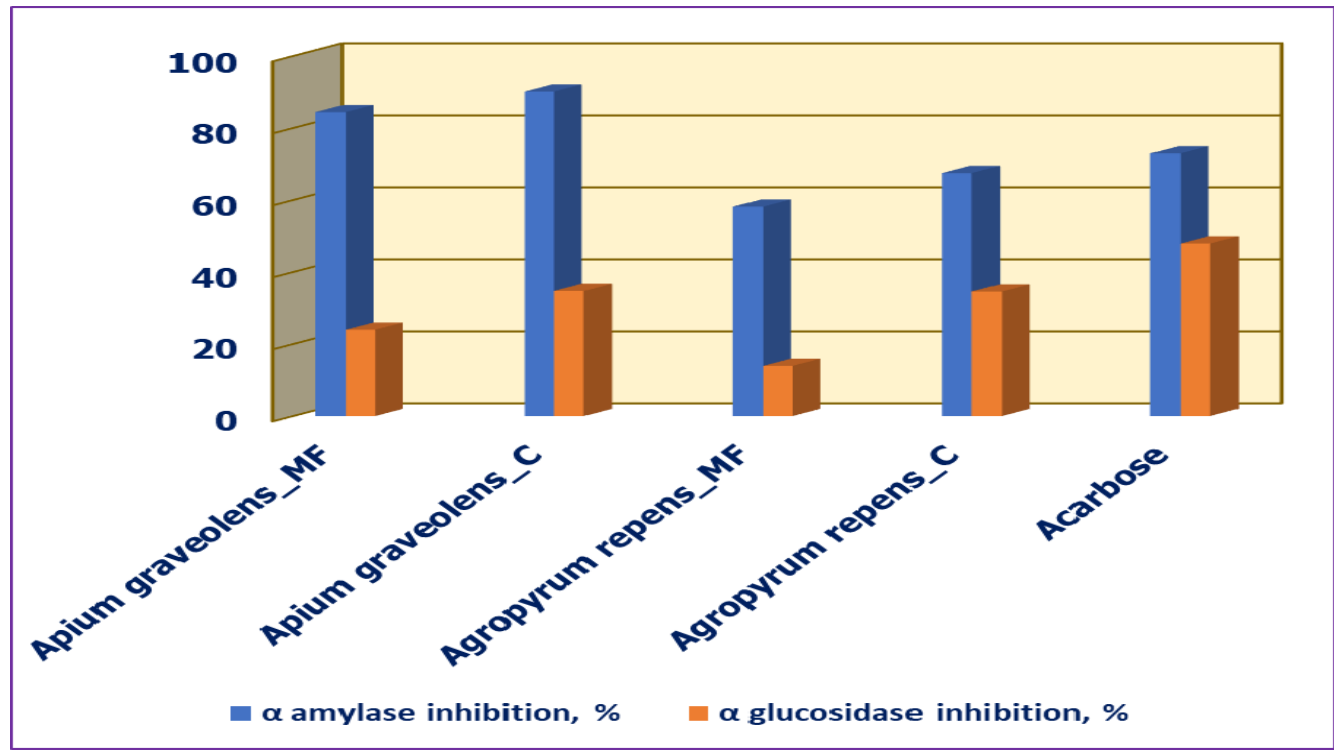

Fig. $2-\alpha$-amylase and $\alpha$-glucosidase inhibition $\%$ by extracts.

Previous studies also suggested that the vegetal extracts rich in phenols showed $\alpha$-amylase and $\alpha$ glucosidase inhibition activities. ${ }^{3-37}$

\section{CONCLUSIONS}

The results obtained revealed a high inhibitory activity of Apium graveolens extracts over 90\% and over $67 \%$ for Agropyrum repens extracts on $\alpha$ amylase, and quite high on $\alpha$-glucosidase for both types of extracts: Apium $-34.75 \%$ and Agropyrum - $34.58 \%$ suggesting that these herbs may be useful in the management of type II diabetes.

Acknowledgements. This research was supported by the Roumanian National Centre for Program Management - PN 19270101 - Contract nr. 25N/2019.

\section{REFERENCES}

1. World Health Organization, Definition, "Diagnosis and Classification of Diabetes Mellitus and Its Complications", Report of WHO, Consultation, Geneva, 1999, p. 66.

2. C. J. Bailey and C. Day, Int. J. Clin. Pract., 2004, 58, 867-876.

3. H. Bischoff, Clin. Invest. Med., 1995, 18, 303-311.

4. C. S. Mizuno, A. G. Chittiboyina, T. W. Kurtz, H. A. Pershadsingh, and M. A. Avery, Curr. Med. Chem., 2008, 15, 61-74.

5. M. A. T. Phan, J. Wang, J. Tang, Y. Zhi Lee and K. Ng, LWT - Food Sci. Technol., 2013, 53, 492-498.

6. G. Oboh, A. J. Akinyemi, A. O. Ademiluyi and F. O. Bello, Afr. J. Pharm. Pharmacol., 2013, 7, 1026-1032.

7. H.-Y Hung, K. Qian, S. L. Morris-Natschke, C-S. Hsu and K-H. Lee, Nat. Prod. Rep., 2012, 29, 590-606.

8. Y. Peng, J. Sun, S. Hon, A. N. Nylander, W. Xia, Y. Feng et al., J. Neurosci., 2010, 30, 8180-9. 
9. H. B. Sowbhagya, Crit. Rev. Food Sci. Nutr., 2014, 54, 389-398.

10. Z. Uddin, A. A. Shad, J. Bakht, I. Ullah and S. Jan, J. Pharm. Sci., 2015, 28, 1699-1704.

11. J. Z. Huang, Y. Z. Chen, M. Su, H. F. Zheng, Y. P. Yang, J. Chen, et al., Neurosci. Lett., 2010, 475, 89-94.

12. F. Grases, M. Ramis, A. Costa-Bauzá and J. G. March, J. Ethnopharmacol., 1995, 45, 211-214.

13. G. Stanic, D. Gavric and I. Simic, Pers. Farm. Glas., 2000, 56, 1-9.

14. H. D. Hagin, J. Agric. Food Chem. 1989, 37, 1143-1149.

15. H. D. Hagin and S. J. Bobnick, J. Agric. Food Chem., 1991, 39, 192-196.

16. D. C. Whitehead, H. Dibb and R. D. Hartley, Soil Biol. Biochem., 1983, 15, 133-136.

17. R. Boesel and H. Schilcher, Planta Med., 1989, 55, 399-400.

18. E. Steinegger, R. Hänsel, "Queckenwurzlstock, Pharmakognosie", 5th. Edition, Springer Verlag, Berlin, Heidelberg, New York, London, 1992, p. 111.

19. U. Koetter, M. Kaloga and H. Schilcher, Planta Med., 1992, 59, 279-280.

20. V. L.Singleton, R. Orthofer and R. M. LamuelaRaventos, Methods Enzymol., 1999, 299, 152-178.

21. "Farmacopeea romana", Editia a X-a, Editura Medicală, București, 1993, p. 260.

22. V. Bondet, W. Brand-Williams and C. Berset, Lebensm. Wiss. U. Technol., 1997, 30, 609.
23. K. Berker, K Guciu, I. Tor and R. Apak, Talanta, 2007, 72, 1157-1165.

24. L. G. Ranilla, Y. I. Kwon, E. Apostolidis and K. Shetty, Bioresour. Technol., 2010, 101, 4676-4689.

25. P. Mccue, Y. I. Kwon and K. Shetty, J. Food Biochem., 2005, 29, 278-294.

26. R. Liu, Am. J. Clin. Nutr., 2003, 78, 517S-520S.

27. J. Vanamala, L. Reddivari and K. S. Yoo, J. Food Comp. Anal., 2006, 19, 157-166.

28. Y. S. Huang and S. C. Ho, Food Chem., 2010, 119, 868873.

29. J. Jiang and Y. L. Xiong, Meat Science, 2016, 120, 107-117.

30. G. Oboh, R. L. Puntel and J. B. T. Rocha, Food Chem., 2007, 102, 178-185.

31. T. Rong, Nutrients., 2010, 2, 1231-1246.

32. M. R. Bhandari, J. A. Nilubon, G. Hong and J. Kawabata, Food Chem., 2008, 106, 247-252.

33. J. S. Kim, T. K. Hyun and M. J. Kim, Food Chem., 2011, 124, 1647-1651.

34. O. A. Ademiluyi, G. Oboh, P. Funmi, M. Aragbaiye Tech, I. Sunday Oyeleye, M. Tech, B. Opeyemi and B. Ogunsuyi Tech, J. Taibah Univ. Med. Sci., 2015, 1-13.

35. H. Wang, Y. J. Du and H. C. Song, Food Chem., 2010, 123, 6-13.

36. P. Wongsa, J. Chaiwarit and A. Zamaludien, Food Chem., 2012, 131, 964-971.

37. S. Y. Wang, M. J. Camp, M. K. Ehlenfeldt, Food Chem., 2012, 132, 1759-1768. 
